\title{
An Observational Study of Organized Snow Echo over the Japan Sea
}

\author{
By Nobuyoshi Shimizu \\ Electronic Computation Center, J. M. A. \\ and \\ Akira Uchida \\ Tokyo International Airport Aviation Weather Service \\ (Manuscript received 28, February 1974, in revised form 2 May 1973)
}

\begin{abstract}
Successive observations of the radar echo which starts from random distribution of convective cells about $200 \mathrm{~km}$ off the coast of the Hokuriku district to form longitudinal multiple echo lines, then transverse lines, and finally but less frequently, vortical echo pattern, denote typical evolution of the echo pattern of heavy snowfall on the Japan Sea side.

The present paper aims to clarify, in more detail, properties, synoptic situation and formation process of the organized snow echo associated with the mesoscale severe phenomenon such as heavy snowfall, using materials obtained by the radar.

Firstly, we measured to find that the mean spacing of the multiple echo lines was $30 \mathrm{~km}$, which is ten times as large as the mean height of the echo top. The observation supports Asai's theoretical result with respect to the spacing of longitudinal cloud bands.

Secondly, the synoptic situation of the mesoscale vortical echo has been specifically examined. Synoptic survey of the environmental condition of the vortical echo was performed for seven samples. Main features commonly observed in the surface pressure pattern are a sharp ridge with the radius of curvature of $100 \mathrm{~km}$ over the mountainous region of Jadan Island, a cyclonic circulation over the Japan Sea and predominadt difference of the vertical wind shear in the lower atmosphere between northern and western parts of the mesoscale vortical disturbance.

Thirdly, the echo band nearly along the discontinuity line of the surface wind field and transverse echo lines intersecting the band were observed as a sign of the subsequent vortical echo. A model of the formation process of the vortical echo is presented in this paper.
\end{abstract}

\section{Introduction}

The Hokuriku district which is located on the coastal area of central Japan facing the Japan Sea is one of the heaviest snowfall region in the world, especially over the plain area. Snowfalls in this region are not uniform, but appear likely to concentrate at the limited area. Phenomenologically, we may classify the type of snowfalls into two categories; i.e., the one over the mountainous region and the other over the coastal plain area.

The first type of snowfalls usually occurs during the developing and mature stages of the winter monsoon. Within the range of two hundred kilometers off the coast, the radar picture first shows random distribution of fine convective cells and then, longitudinal multiple echo lines according to the stages of the monsoon.

On the otherhand, the second type of snowfalls occurs during the decaying and the final stages of the monsoon. In this case, the transversely aligned echoes are usually observed. Sometimes, we observe the vortical echo which brings heavy snowfall.

It should be noted that the line or band structure of the radar echo plays an important role for the two types of snowfalls. The band structure of the air motion similar to our band structure has been studied by many authors e.g., Kuettner (1959), Higuchi (1963), Malkus (1963), Tsuchiya and Fujita (1967) and Miyazawa (1968). Orientation of the band is almost in the direction of the 
thermal wind in the lower atmosphere (Malkus and Miyazawa). Matsumoto et al. (1968) analyzed a lined-up cumulus row along the coast of the Hokuriku district and found local convective warming in the lower atmosphere.

Mechanism for maintaining the band structure was analyzed by Tatehira and Fukatsu (1963). The source region of the echo is the upstream part of the band. Theoretical treatment of the longitudinal cloud band was made by Kuo (1963) and Asai (1968). Longitudinal roll clouds in the atmosphere are predominant when the shearing flow is present and the stratification is unstable. Asai suggested that the spacing of the bands is ten times as large as the depth of the convective layer. Later Asai (1972) investigated thermal convection in a shear flow varying the directions as well as the speed with respect to height by means of the perturbation analysis. $\mathrm{He}$ found that the thermal instability yields a preferred mode of convection roll whose axis is in the direction of the vertical wind shear.

Another approach to heavy snowfalls over the plain area has been made by many authors from synoptic and theoretical points of view. A minor cold vortex which is cut off from the polar major vortex has been recognized as the primary and main cause of snowfalls over the plain region. The surface pressure pattern with the cyclonic curvature over the sea area is often called 'Fukuro (bag) type' which has been recognized by the synoptic meteorologists as a significant measure for the snowfall forecast over the plain area.

Sensible heat transports from the sea surface and the latent heat release due to the condensation are considered supplemental causes for maintaining the cyclonic pattern of the surface pressure field (Gambo 1963, Nitta 1964). The discontinuity line of surface wind field was the main subject of meteorological studies in the pre-radar era. Meandering of the discontinuity line and the formation of the small disturbance on the line were first discovered by Sugiyam (1949) using the surface observation. After the time when the radar data became available, Miyazawa (1967) found a vortical echo which has the positive vorticity of the order of $10^{-3} \mathrm{sec}^{-1}$ and the convergence of slightly smaller magnitude.

However, the formation process of the vortical echo has not yet been clarified. Since the finding of the vortical echo by Miyazawa, several vortical echoes have been observed by weather radars installed along the coast of the Japan Sea. The detailed description of the whole process of the evolution associated with the vortical echo remains to be studied. Furthermore, from the practical point of view, the early detection of the vortical echo may be utilized as a useful indication of heavy snowfall for issuing the correct warning in time.

The present paper aims at mainly clarifing the manner of the formation of the vortical echo. Especially, the manner of transformation of the band structure is considered to be the important feature to results in the vortical echo. Under these circumstances, present authors dealt with several samples to visualize the averaged evoluting process of the radar echo in conection with heavy snowfalls. In this work, we used PPI pictures taken at Tojinbo and PPI cinefilm taken at Yahiko as the material for the echo analysis (Section 2). A typical example of the radar echo for heavy snowfall observed at Tojinbo is shown in Section 3. In order to estimate the orientation, the spacing of echo lines and its relation to the stratification of the lower atmosphere, we treated the record of several line echoes statistically and examined the agreement with the Asai's result. Results are described in Section 4. In Section 5, the surrounding synoptic situations for the several vortical echoes were investigated in more detail to know definite and common features. Section 6 shows the formation of vortical echo using the radar observation for two cases (i.e., on Jan, 2, 1969, by Yahiko radar and on Feb. 9, 1973, by Tojinbo radar).

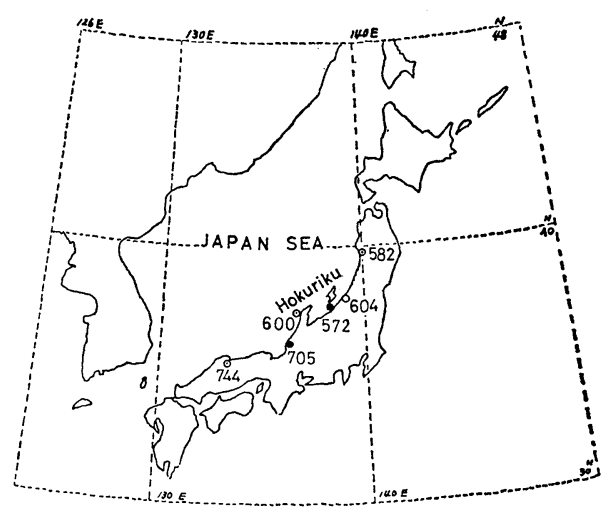

Fig. 1. The locations of radar sites $(\bullet)$ and upper air stations $(\odot)$ around the Hokuriku district. 


\section{Materials}

In order to serve the geographical arrangement, the location of the Hokuriku district is shown in Fig. 1. The present work was performed using materials obtained by Tojinbo racar (station number 47705). In addition to this, radar pictures obtained by Yahiko radar (47572) were also taken up. Aerological data obtained at stations Wajima (47600) and Yonago (47744) were used for synoptic survey. Daily printed charts for the surface and upper levels, issued by the Japan Meteorological Agency (JMA), were utilized as supplemental materials.

\section{Typical evolution of echo pattern}

A time sequence of radar pictures and upper air observations during the period from Jan. 18 through Jan. 21, 1966 are shown in Fig. 2. The

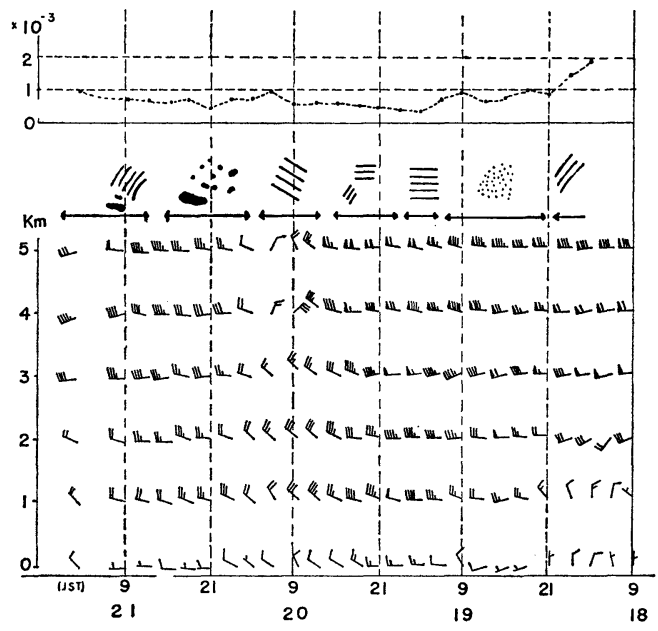

Fig. 2. Time sequence of characteristic echo patterns (middle) at Tojinbo and upper air observations at Wajima during the period from 0900 JST (0000 GMT) Jan. 18 to 0600 JST Jan. 21, 1966. Static stability for the layer of $700-850 \mathrm{mb} \mathrm{mb}$ in unit of $\mathrm{m}^{2} \mathrm{sec}^{-2} \mathrm{mb}^{-2}$ (upper) and vertical wind in knots (lower).

typical evolution of the echo pattern may be seen in the figure.

First, we may observe the random distribution of convective fine cells over the Japan Sea at the initial stage of the outbreak starting form 21 JST Jan. 18 to the next morning. After about a half day, the typical longitudinal multiple echo lines are formed on 12 JST Jan. 19 in correspondence to the mature stage of the winter monsoon. In this stage, the static stability between 700 and $850 \mathrm{mb}$ decreases to the minimum and the wind speed becomes 30 knots in the lower troposphere. The vertical shear of wind speed is about 20 knots $/ \mathrm{km}$. Kuettner's curved wind profile with altitude is not clearly observed in this case. Scattered echo cells after the destruction of the longitudinal lines i.e., 21 JST on 20 look different from the random distribution at the beginning stage on 18 in the size of cells. As time advances, the organization of the transverse alignment takes place on Jan. 21 along with the other band which elongates in perpendicular to the multiple lines. The orientation of the transverse type is roughly in the direction of the low level wind shear vector. Unfortunately, we have no subsequent observation. After a break of one day, we have the radar observation which indicates the vortical echo pattern (09 JST Jan. 22). Although we have no information about the transient process, it should be noted that the vortical echo was observed after the transverse alignment. Fig. 3. and Fig. 4. (after Miyazswa 1967) show typical pictures of the longitudinal and the vortical echo, respectively.

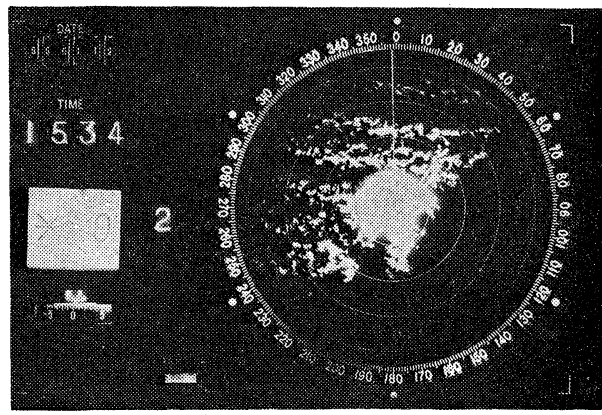

Fig. 3. PPI picture at 1534 JST Jan. 19, 1966. (Tojinbo radar)



Fig. 4. The same as Fig. 3 but for 1030 JST Jan. 22, 1966. After Miyazawa. 


\section{Spacing of zaligned echo lines}

The spacing of the longitudinal and convective cloud band was theoretically estimated by Asai (1968) under the assumption that the preferred mode should be the one which makes the upward heat trassport maximum. No attempt has so far been made to estimate statistically the size from the observation except some case studies. The fact that aligned echo pattern dealt in our study seems to be similar to the Asai's theoretical model in their appearance motivated the evaluation of the size of spacing from the record of the radar observation.

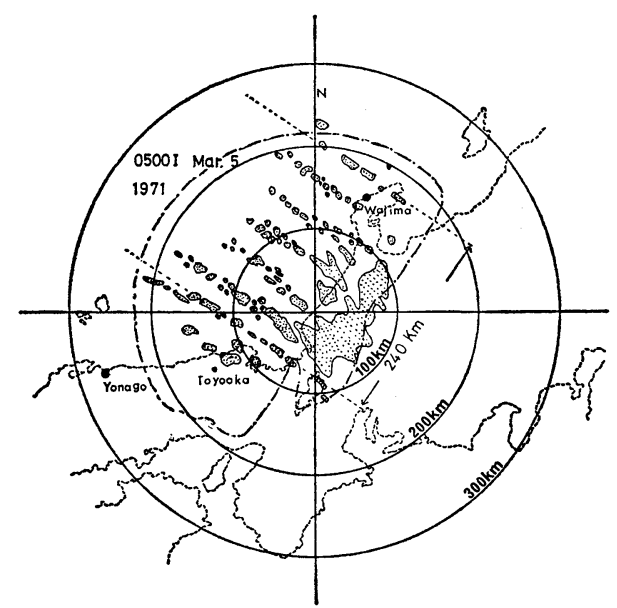

Fig. 5. Typical echo pattern showing longitudinal echo lines over the sea area. The spacing of the echo lines is $40 \mathrm{~km}$. Orientation is in the direction of $310^{\circ}$. Radar horizon with geographical correction is shown in dot-dashed line for the height of $2.0 \mathrm{~km}$.

An example of the longitudinally aligned pattern is shown in Fig. 5. The radar horizon with the geographical correction is shown in the dot-dashed line for the height of $2.0 \mathrm{~km}$. Although the inland detectable area is limited, we may say that the stratus echo covers the mountainous area of the Japan Sea side. On the other hand, at the same time, cumulus echo cells are observed in parallel lines over the sea area. The spacing of the echo lines is $40 \mathrm{~km}$. The lines point to the direction of approximately $310^{\circ}$ in this example.

For the purpose of the statistical estimation of the spacing, we selected 126 definite aligned patterns from pictures obtained at Tojinbo during the winter period from 1966 to 1971. These sample pattern were taken up at intervals of one hour from highly frequent observation. We evaluated the orientation, the spacing and the height of the echo top in each pattern.

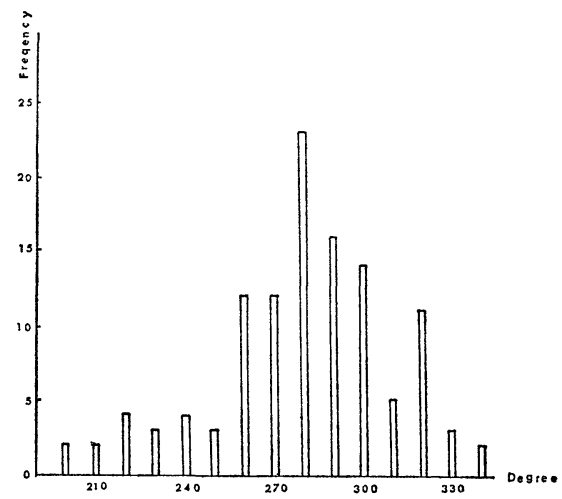

Fig. 6. Distribution for the orientation of aligned echo lines. Westward direction in the abscissa.

Fig. 6 shows distribution for the orientation of aligned echo lines. The longitudinal mode of the aligned echo lines whose orientation is approximately in the width of the direction between $260^{\circ}$ and $330^{\circ}$ is far more frequently observed than the other. Fig. 7a shows the distribution for the size of the spacing. About seventy percent of the total are in $20-40 \mathrm{~km}$ range. The average size of the spacing is $30 \mathrm{~km}$ which is ten times as large as the mean height of the echo top.

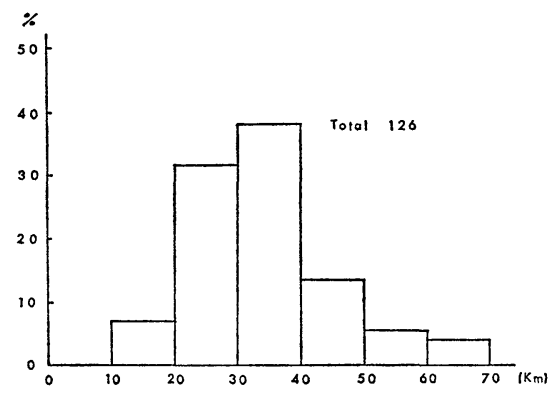

Fig. 7a. Distribution for the spacing of echo lines during the winter period from 1966 to 1971.

The ratio of the spacing to the height of the echo top correlates with the static stability in the lower atmosphere estimated with the aerological data at Wajima and Yonago (Fig. 7b). The spacing is wider if the echo top is high for the constant stability and also wider if the atmosphere 


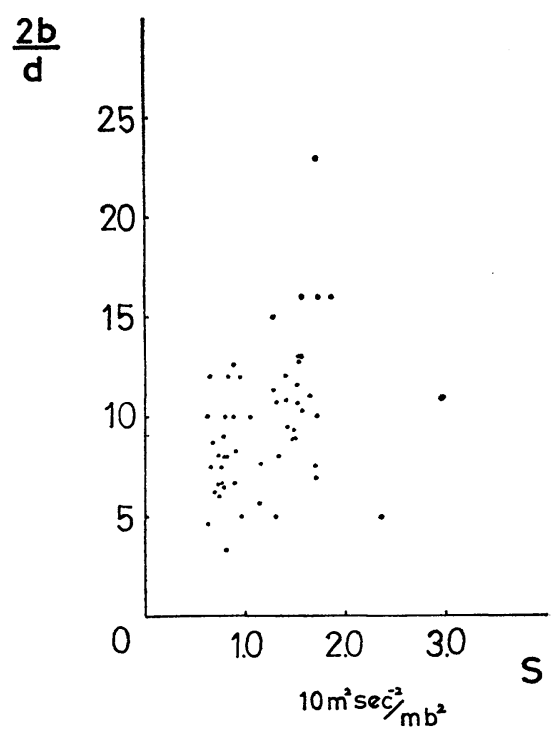

$$
S=2 S w+S y / 3
$$

Fig. 7b. Distribution of the spacing divided by the height of echo top with respect to the static stability. (2b: the spacing of multiple echo lines, $\mathrm{d}$ : the height of echo top, s: the static stability between 700 and $850 \mathrm{mb}$ ).

is more stable for the constant height of the echo top. The result supports at Asai's theoretical estimation concerning the spacing of the longitudinal and convective cloud band.

\section{Vortical echoes and synoptic situations}

Fig. 8, 9 and 10 illustrate fully developed vortical echoes with the eye. The diameter of the eye is about ten times as large as the height of the surrounding echoes. We should first emphasize the fact that the spiral band is composed of many line echoes and conspicuously seen in rear side of the center. Wavy patterns are also seen in Figs. 8 and 10. Fig. 11 denotes an example of the inmature vortical echo without the eye. Surface charts corresponding to these radar echoes are illustrated in Figs. 12, 13, 14 and 15.

In addition to the cyclonic pressure pattern over the sea area, we can see an outstanding surface ridge over the inland mountainous area. The radar range then cover the area where little pressure gradient is observed. The anticyclonic area with

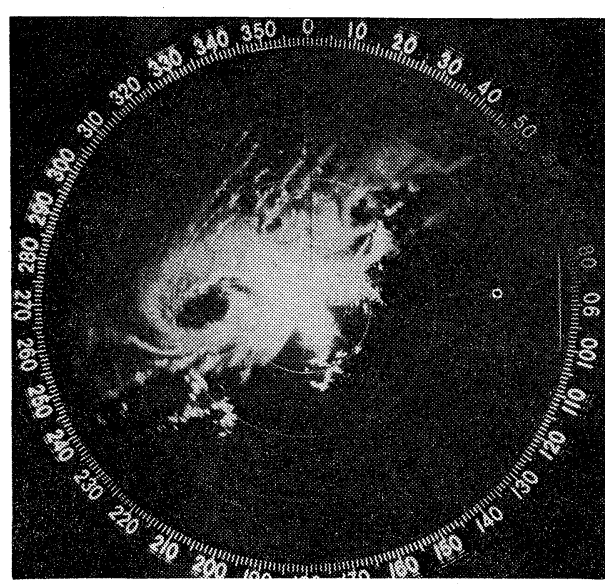

Fig. 8. PPI picture at 0454 JST Feb. 9, 1968 (Tojinbo radar). Range markers are at intervals of $50 \mathrm{~km}$. After Nishio (1969).

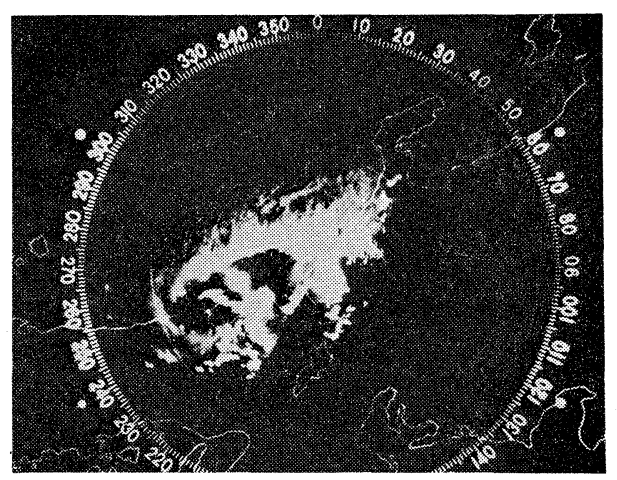

Fig. 9. PPI picture at 2220 JST Mar. 19, 1970. Range markers are at intervals of $50 \mathrm{~km}$.

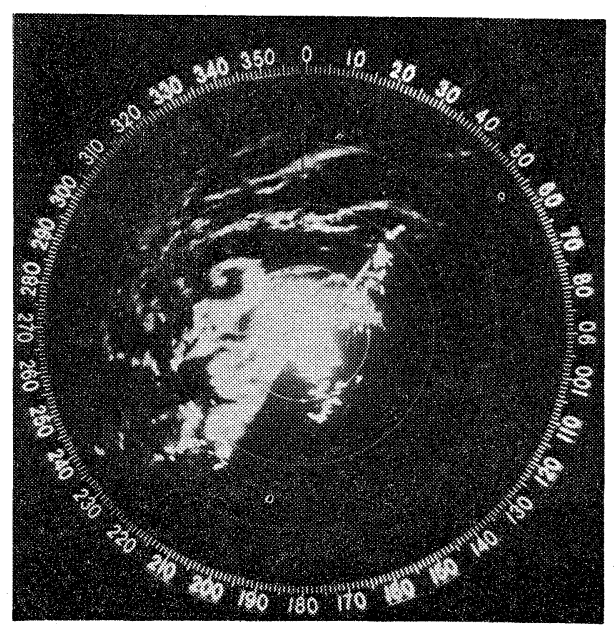

Fig. 10. The same as Fig. 9 but for 0928 JST Mar. 6, 1971. 


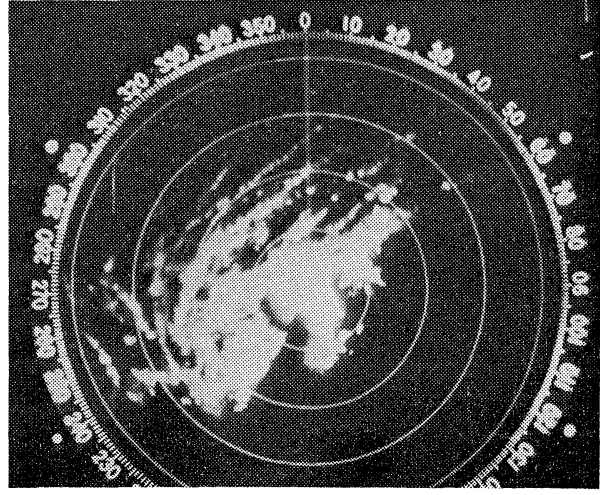

Fig. 11. The same as Fig. 9 but for 2116 JST Jan. 16, 1970.

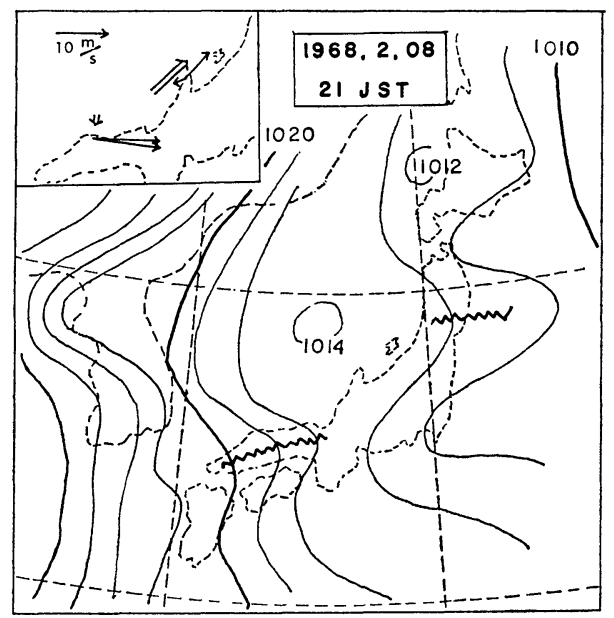

Fig. 12. Surface pressure chart at $2100 \mathrm{JST}$ Feb. 8, 1968. Doubled vector and single vectors show wind shear and wind at $700 \mathrm{mb}$ and $900 \mathrm{mb}$ respectively. The magnitude of 10 $\mathrm{m} \mathrm{sec}-1$ is shown by the arrow.

the radius of curvature of the order of $100 \mathrm{~km}$ corresponds to the fully developed vortical echo with the eye. (Compare, for example, Figs. 12, 13 and 14 with Figs. 8, 9 and 10) On the other hand, the anticyclonic area with the relatively larger radius of the curvature (Fig. 15) corresponds to the vortical echo without the eye shown in Fig. 11. A great difference between the northern and the western parts of the disturbance is also found in the vertical wind shear shown in the upper left of each figure. The orientation of the spiral band agrees with the direction of the vertical wind shear at Wajima.

We discuss briefly about the event on March

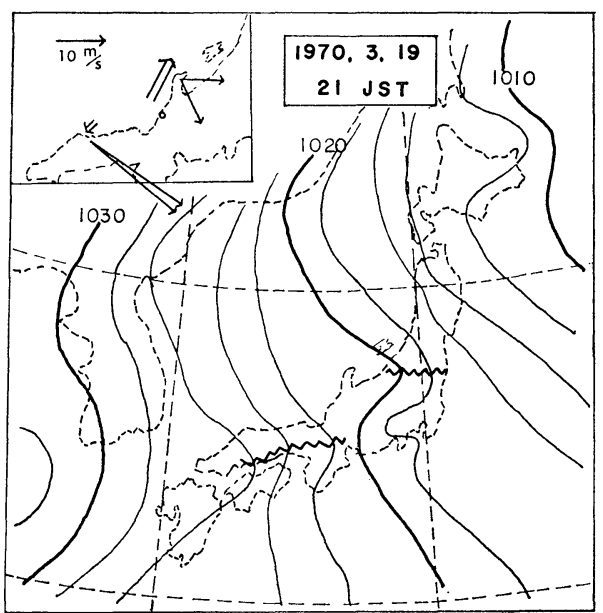

Fig. 13. The same as Fig. 12 but for 2100 JST Mar. 19, 1970.



Fig. 14. The same as Fig. 12 but for 0900 JST Mar. 6, 1971.

19, 1970. Contour lines and isotherms of $-40^{\circ} \mathrm{C}$ and $-45^{\circ} \mathrm{C}$ on the $500 \mathrm{mb}$ level are shown in Fig. 16, respectively. The vortical echo is located at the north of the maximum wind zone at 500 $\mathrm{mb}$ and at the south of the cold region at $500 \mathrm{mb}$ stippled in Fig. 16. The time sequence of surface observations at Toyooka during the period of the vortical echo is shown in Fig. 17. The center of the echo passed at about 2200 JST March 19, 1970. A pressure fall of about $0.6 \mathrm{mb}$ on the rising trend, the rapid temperature increase by $0.7^{\circ} \mathrm{C}$ and the humidity decrease by $15 \%$ are seen in the figure in association with the passage of the center. The weak southerly wind in front of and 


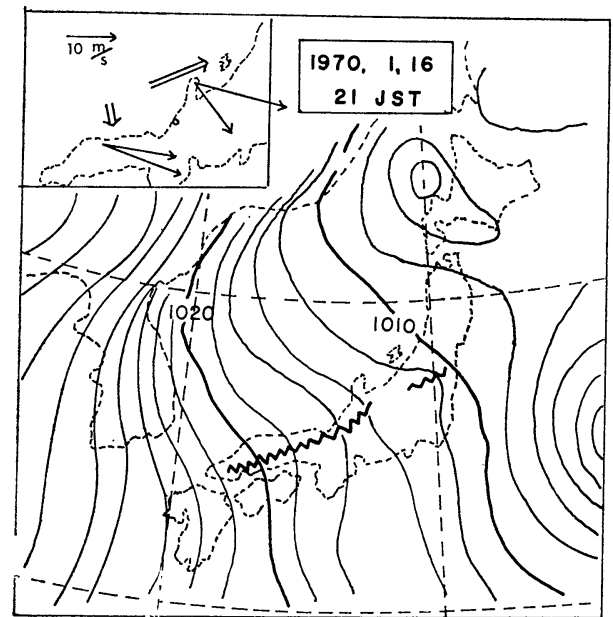

Fig. 15. The same as Fig. 12 but for 2100 JST Jan. 16, 1970.

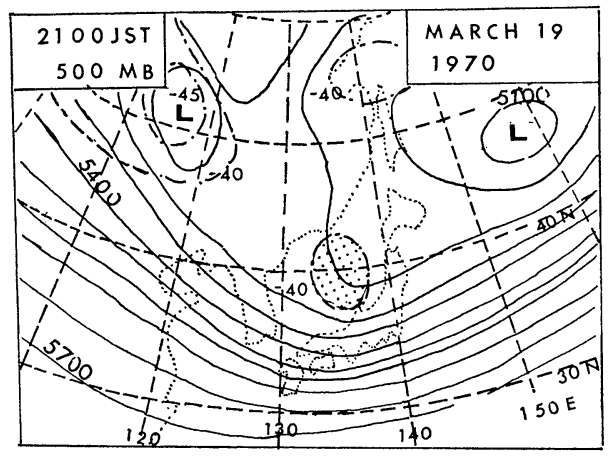

Fig. 16. Contours and isotherms of $--40^{\circ} \mathrm{C}$ and $-45^{\circ} \mathrm{C}$ at $500 \mathrm{mb}$ surface at 2100 JST on Mar. 19, 1970.
TOYOOKA MAR.19 1970

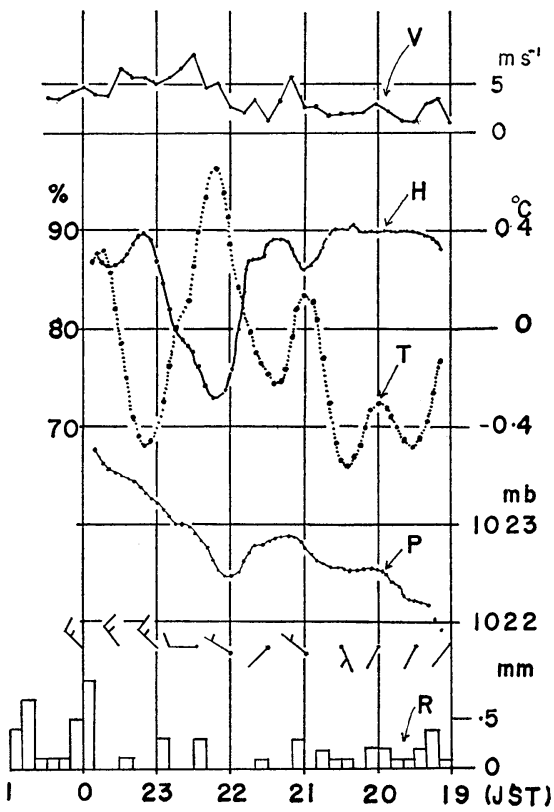

Fig. 17. Time sequence of surface elements at Toyooka during the passage of the center of the vortical echo on Mar. 19, 1970. Pressure, temperature and humidity are shown with five terms running mean operations. V.H.T.P. and $\mathrm{R}$ denote mean wind speed in ten minutes, humidity, temperature, pressure and precipitation respectively. Wind is shown in conventional knots.

Table 1.

\begin{tabular}{|c|c|c|c|c|c|c|c|c|}
\hline Date and time & 1 & & 2 & 3 & & 4 & Eye & Author \\
\hline $1966,1,22,1000$ & 0 & $S$ & -36.3 & 0 & 0 & $100 \mathrm{~km}$ & 0 & Miyazawa (1967) \\
\hline $1968,2, \quad 09,0500$ & 0 & SE & -36.7 & 0 & 0 & $70 \mathrm{~km}$ & 0 & Nishio (1969) \\
\hline $1970,1,16,2100$ & $\mathrm{O}$ & $\mathrm{SE}$ & -44.5 & 0 & 0 & $230 \mathrm{~km}$ & $x$ & \\
\hline $1970,3,19,2100$ & 0 & $\mathrm{~S}$ & -43.9 & 0 & 0 & $130 \mathrm{~km}$ & 0 & \\
\hline $1971,3,06,0900$ & 0 & $\mathrm{E}$ & -33.7 & 0 & 0 & $60 \mathrm{~km}$ & 0 & \\
\hline
\end{tabular}

1; Vortical echo is observed in the northern side of maximum wind zone at $500 \mathrm{mb}$ surface.

2; Vortical echo is located south or southeast of cold air at $500 \mathrm{mb}$ surface. Temperature at Wajima is as cold as $-35^{\circ} \mathrm{C}$.

3; Great difference in vertical wind shear as sociated with vortical echo.

4; The surface pressure pattern is so-called 'Fukuro (bag) type'. The radius of curvature of the inland ridge is about $100 \mathrm{~km}$. 


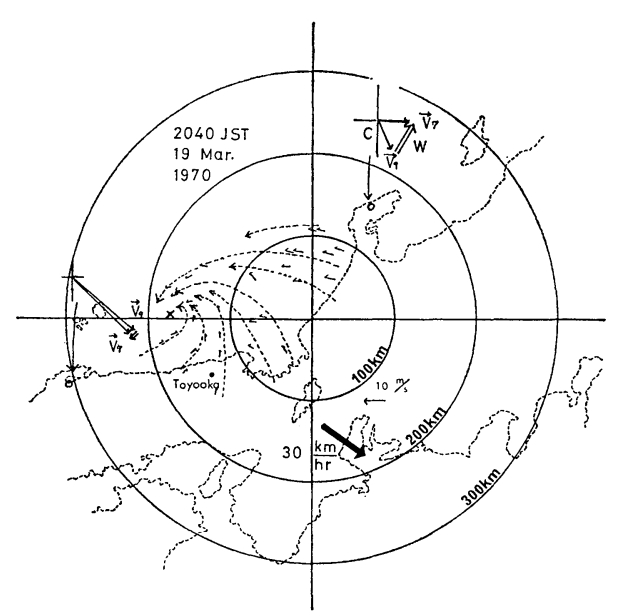

Fig. 18. Relative motion of echo cell to the track of the center in the intervals of 15 minutes from 2032 to 2047 JST on Mar. 19, 1970.

the strong northerly wind in rear of the center indicate cyclonic circulation of the disturbance. The rapid increase in precipitation after the passage of the center is attributed to the spiral echo band on the rear side of the eye. The motion of echo cells relative to the track of the center is derived from the displacement of the echo cell with the interval of 15 minutes from 2032 JST to 2047 JST and the result is shown in Fig. 18. The cyclonic circulation is notified in the figure.

The result mentioned above are more or less commonly observed in the synoptic patterns for the vortical echo. For the sake of convenience, general synoptic features associated with the vortical echo observed by Tojinbo radar are summarized in Table 1 for five examples.

\section{Formation process of the vortical echo}

In this section, we will discuss about the formation process of the vortical echo, based on detailed observations on Jan. 2, 1969 by Yahiko radar and on Feb. 9, 1973 by Tojinbo radar. From the practical point of view, it is important to detect the sign of the development of the vortical echo as early as possible for the timely warning of heavy concentrated snowfall as was mentioned in section 1.

Fig. 19 shows the band echo extending from the west to east along the coast and multiple line echoes over the sea intersecting the west-east band. The whole system moved to east to southeastwards with the speed of $30 \mathrm{~km} / \mathrm{hr}$. After two

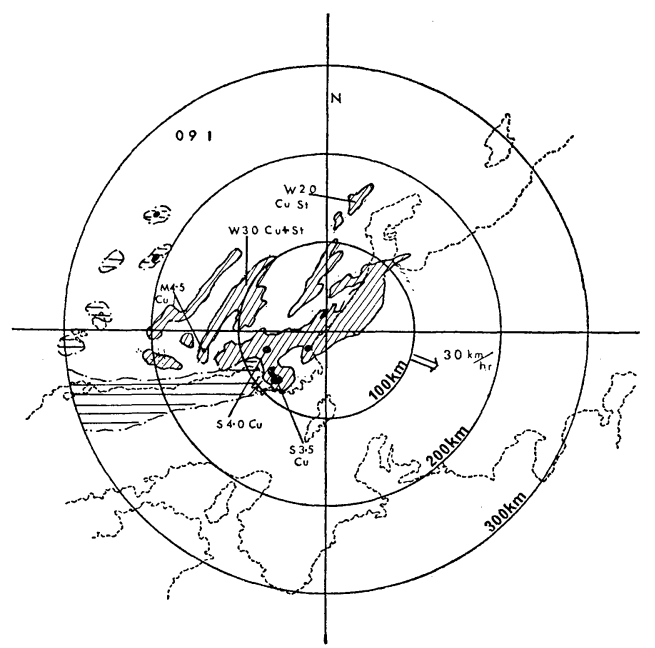

Fig. 19. Radar skech at 0900 JST Feb. 9, 1973 by Tojinbo radar and Matsue radar. Differently hatched area are referred to the sketch of Matsue. Expressions are conventional.

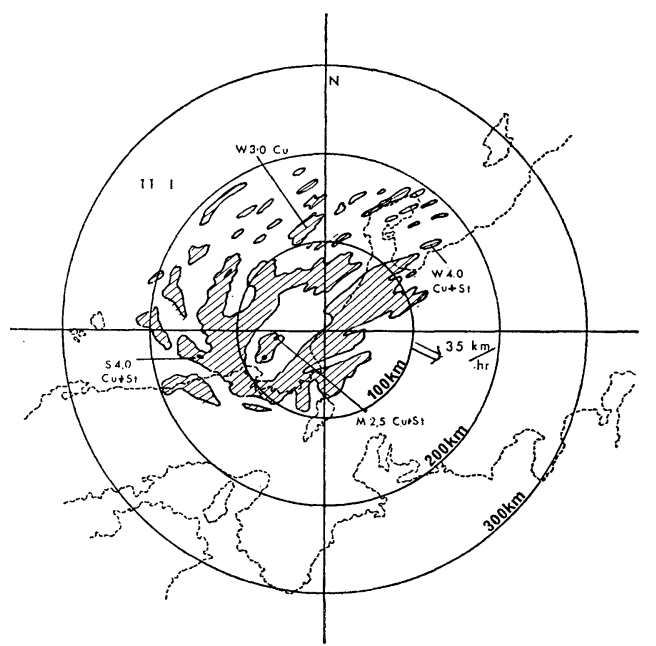

Fig. 20. Radar sketch at 1100 JST Feb. 9, 1973 by Tojinbo radar.

hours later, this line echo pattern changed to show a vortical configuration as is seen in Fig. 20. This evolution process from the line echo pattern to vortical echo pattern repeated about every three hours from morning until evening for three times. The largest accumulated amount of snowfall was recorded at the land stations located in the plain area at western Hokuriku in this winter season.

Another example of the spiral echo pattern is shown in Fig. 21. Two systems of line echoes are observed to intersect each other by the radar picture. Although no satillite observation is 


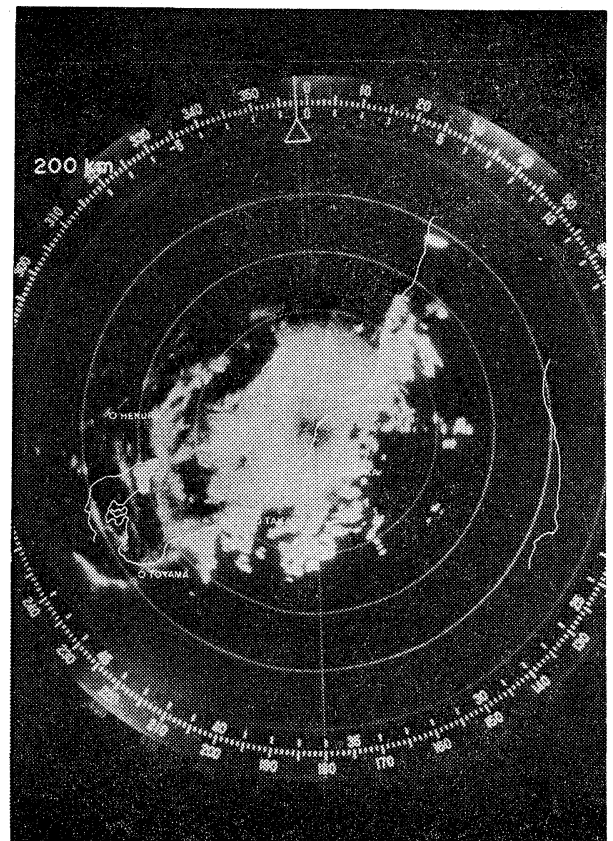

Fig. 21. PPI picture at 1515 JST Jan. 2, 1969 by Yahiko radar. Range markers are at intervals of $50 \mathrm{~km}$.

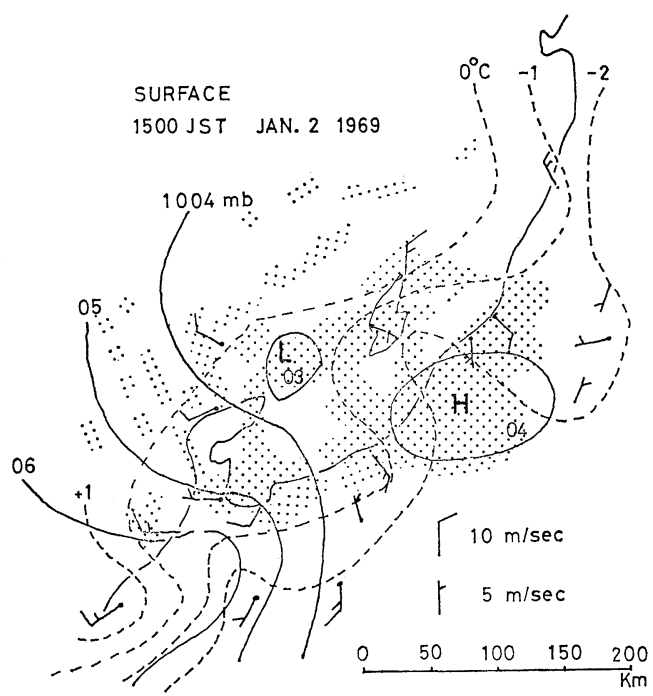

Fig. 22. Local surface chart at 1500 JST Jan. 2, 1969. Echo cover by the skech of Yahiko is shown in stipled area.

illustrated in the present paper, we find a thick cloud band over the intersecting zone in the satillite picture. Fig. 22 is the surface local map on Jan. 2, 1969 showing a mesoscale cyclone situated innermost side of curved echo bands. A ridge and a mesoscale anticyclone in the pres- sure field are also seen on the inland area. The whole cycle of formation of the spiral band and invasion to the inland area frequently occured one after another during the day from morning through evening.

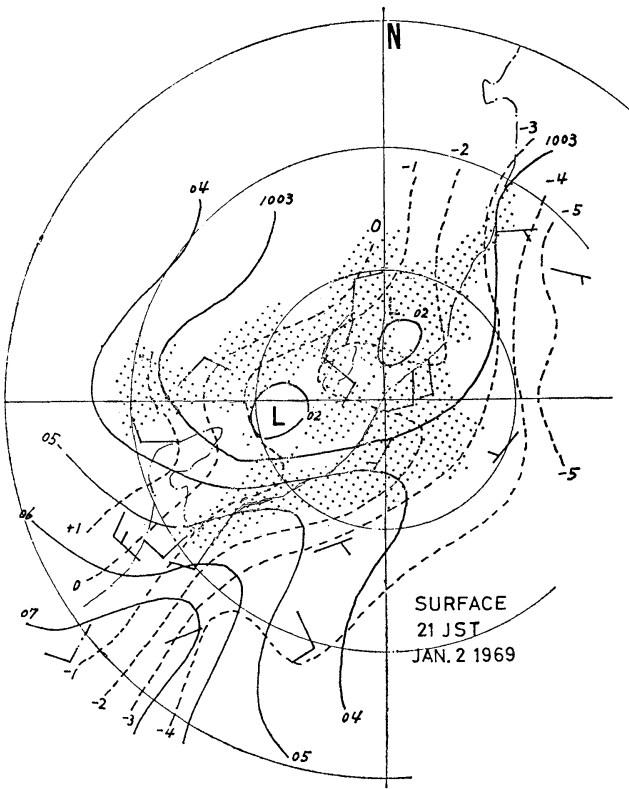

Fig. 23. The same as Fig. 22 but for 2100 JST Jan. 2, 1969.

Fig. 23 shows the surface local map observed six hours later from Fig. 22. In comparison with pattern in Fig. 22, the inland ridge has completly formed. Two mesoscale lows are located about $120 \mathrm{~km}$ apart on the sea area. The mesoscale cyclones which are mentioned above were analyzed using the recording papers of surface observations. We can assure in Fig. 23 that the existence of the line echo situating along coast line over the Japan Sea about $30 \mathrm{~km}$ off the coast and a circular echo superposing upon the line echo to the north of Wajima.

The process of formation of the circular echo was investigated by using the movie of the time lapes film pictured every 30 seconds. The formation process may be classified into three stages as follows;

1), At about $2030 \mathrm{JST}$, relatively strong convective cells began to appear in the secene of the movie.

2), About ten minutes later, the cells started to rotate counterclockwise. Faint spirals were seen in this stage which locked as if each 
convective cell drew the trail.

3), The circular echo pattern, broken partly in the southern corner, was formed by 2130 JST. Fig. 24 shows a circular echo pattern, broken partly in the southern corner, superposing on the line echo which was $30 \mathrm{~km}$ off the coast. New convective cells were developing in the southern broken part. Thes enew cells took part in the formation of ring shaped echo with inner diameter of $20 \mathrm{~km}$ as is shown in Fig. 25 .

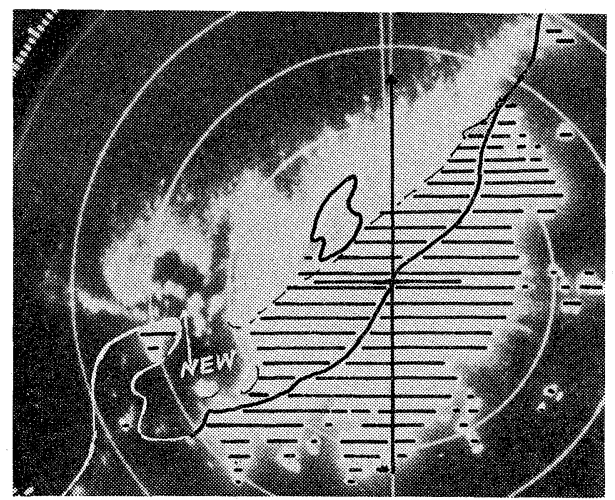

Fig. 24. PPI picture at 2148 JST Jan. 2, 1969. Sea and groung clutter are hatched. New convective cells were developing near the center.

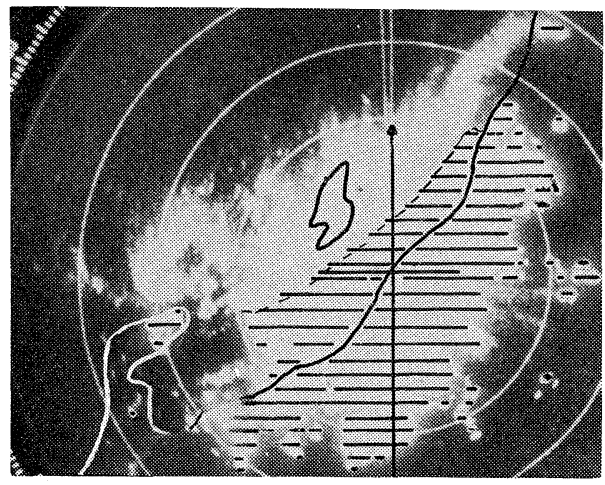

Fig. 24. PPI picture at 2215 JST Jan. 2, 1969, 27 minute later from Fig. 24. Ring echo with inner diameter of $20 \mathrm{~km}$ supperposing upon the line echo was formed.

The circular echo mentioned above is considered the eye of the vortical echo. The height of the echo top around the eye was nearly $5.0 \mathrm{~km}$. The penetrative echo cells have been commonly observed in the record of vortical echo. This process that new convective cells develope and take part in the formation of the ring-shaped echo is similar to the case of the formation of the typhoon eye wall as was analyzed by Tatehira (1962). The present phenomenon discussed here is, however, dissipated much more rapidly with the life time of several hours.

Finally, based on the obove observatonal results, we may propose a model of the formation process of the vortical echo as is illustrated in Fig. 26.

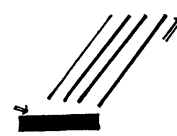

a

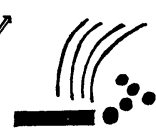

b

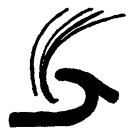

c
Fig. 26. A proposed model of the formation process of vortical echo.

a; Initial stage showing west-east band and transverse multiple echo line intersecting the band. Vertical wind shear in the lower atmosphere are shown by the double arrows.

$\mathrm{b}$; Developing stage showing showing spiral appearance and growing echoes.

c; Mature stage with the eye.

Although the so-called Hokuriku discontinuity line, the mesoscale low over the sea off the coast and mesoscale high over the inland mountainous region are not discussed in detail, they are all connected to lead to the situation which is favorable to form the vortical echo. No theoretical explanation has so far been proposed for the observed evolution of the radar echo presented in this article.

\section{Acknowledgements}

The present study was completed during the first author's stay at Tojimbo radar site and the second author's stay at Niigata District Observatory. It is a great presure that this study is supported by the research fund from the Meteorological Society of Japan. The present authors wish to thank to the Society. Also, they would like to express their hearty thanks to Dr. Takashi Nitta for his kind encouragement throughout the study, for reading the manuscript and for giving valuable comments. Thanks are due to Mr. M. Saruhashi and Mr. H. Kawabata for their kind assistance in processing materials. 


\section{References}

Asai, T., 1968: On the spacing of convective cloud bands. Special Contributions, Geophisical Institute, Kyoto Univ. 8, 21-30.

- 1972: Thermal instability of a shear flow turning the direction with height. J. Met. Soc. Japan, 50, 525-532.

Gambo, K., 1963: The role of sensible heats in the baroclinic atmosphere. J. Met. Soc. Japan, 41, 233-246.

Higuchi, K., 1963: The band structure of snowfall. J. Met. Soc. Japan, 41, 53-70.

Kuttner, J., 1959: The band structure of the atmosphere. Tellus, 11, 267-246.

Kuo, H. L., 1963: Perturbations of plane Couette flow in stratified fluid and the origin of cloud street. The Physics of Fluids, 6, 195-211.

Malkus, J. S., 1963: Cloud patterns over tropical oceans. Science, 141, 767-778.

Matsumoto, S., K. Ninomiya and T. Akiyama, 1968: Mesoscale analytical study on a lined-up cumulus row caused by orographic effect under the winter monsoon situation. J. Met. Soc. Japan, 46, 222233.

Miyazawa. S., 1967: On vortical disturbances observed during the period of heavy snow or rain in the
Hokuriku district. J. Met. Soc. Japan, 45, 166176.

, 1968: A mesoclimatological study on heavy snowfall-A synoptic study on the mesoscale disturbances. Papers in Meteor. Geophys., 19, 487550.

Nishio, K., 1969: Recent radar observation (9). Technical News, Tokyo District Meteorological Observatory 10.

Nitta, T., 1964: On the development of the relatively relatively small scale cyclone due to the release of latent heat by condensation. J. Met. Soc. Japan, 40, 260-268.

Sugiyama, K., 1949: On meandering of Hokuriku discontinuity line and cause of heavy snowfall. Jour. Met. Rec. 1, 96-100.

Tatehira, R. and H. Fukatsu, 1963: Radar and mesoscale analysis of a cold front. J. Met. Soc. Japan, 41, 145-157.

- 1962: Radar and mesoscale analysis of rainband in typhoon Geogia in 1959. Jour. Met. Rec. 14, No. 9, 13-22.

Tsuchiya, K. and T. Fujita, 1967: A satellite meteorological study of evaporation and cloud formation over the western Pacific under the influence of the winter monsoon. J. Met. Soc. Japan, 45, 232-250.

\title{
組 織された雪エコーの観測 的研 究
}

\author{
清 水喜 允・内 田亮 \\ 気象庁予報部電子計算室・東京航空地方気象台管制気象課
}

日本海側の沿岸平野部の大雪と関連するうず状エコーの形成過程の研究が，適切な局地集中降雪の予報のために必 要である. 日本海で観測される雪のエコーパターンは, 吹出し初期のランダムな対流セルの分布, 最盛期の一般流に 平行な綎整列線エュー，衰弱期の横整列線エコー，そして稀ででるがうず状エコーが特徵的である.

整列した線エコーパターンは多くは一般流に平行で, 線エコー相互の間隔は平均 $30 \mathrm{~km}$ でェコー頂高度の約 10 倍 であった．この結果は浅井（1968）の，バンド状雲列の間隔に関する理論的結論を支持する.

らず状エコーの観測される条件は，いわゆる里雪大雪の綜観場であるが（宮沢 1967）, 著者は地上気圧場の日本列 島に位置する曲率半径 $100 \mathrm{~km}$ 程度のシャープなりッジが存在し, 風の鉛直シアーの場に著しい变化があることを指 摘する。

二例の観測によって，らず状ェコーは西から東にのびるバンドェコーに，北東から南西に走向する線エコーが斜交 するとき，万忘述べた綜観場の中で形成されることがわかった．数個の高い対流セルが反時計名りに回転し，リン グ状となり，らず状ェコーの中心の眼になることが指摘される. 